ORIGINAL ARTICLE

\title{
Polymorphisms of CD14 gene and TLR4 gene are not associated with ulcerative colitis in Chinese patients
}

\author{
Q S Guo, B Xia, Y Jiang, S A Morré, L Cheng, J Li, J B A Crusius, A S Peña
}

See end of article for

authors' affiliations

Postgrad Med J 2005;81:526-529. doi: 10.1136/pgmj.2004.030825

.....................

Correspondence to:

Professor B Xia

Department of Internal

Medicine and Geriatrics,

Wuhan University

Zhongnan Hospital, No

169 Donghu Road,

Wuhan 430071, Hubei

Province, PR of China;

bingxia2004@yahoo.

com.cn

Submitted

18 November 2004

Accepted 10 January 2005

\begin{abstract}
Background and aims: Toll-like receptor 4 and $C D 14$ are the components of the lipopolysaccharide receptor complex. The aim of this study was to investigate the associations between polymorphisms TLR4 Asp299Gly and CD14 C-260T and Chinese patients with ulcerative colitis (UC).

Methods: Using a polymerase chain reaction based restriction fragment length polymorphism, the study genotyped polymorphisms TLR4 Asp299Gly and CD14 C-260T in 114 patients with UC and 160 healthy controls in the Chinese Han population. Moreover a comparison was made with 170 healthy Dutch white subjects.

Results: No TLR4 Asp299Gly mutation was detected in any patients or healthy controls in the Chinese Han population, which was similar to Japanese subjects, but the mutation occurred in $10 \%$ of the Dutch white subjects. There were no significant differences of CDI4 genotypes between healthy controls and the patients with UC.
\end{abstract}

1 nflammatory bowel disease (IBD) comprises mainly ulcerative colitis (UC) and Crohn's disease (CD) characterised by long term intestinal inflammation attributable to an exaggerated immune response. The aetiology is still unknown. Genetic susceptibility has been shown by epidemiological and genetic investigations. ${ }^{1}$ Recent genome-wide linkage studies and case-control association studies have shown several susceptibility regions for IBD and identified the CARD15 (NOD2), the first susceptibility gene for CD. NOD2 is a cytosolic protein expressed in monocytes and involved in the immune response to peptidoglycan (MDP) via the activation of NF- $\kappa B .^{2-5}$ The studies confirm that IBD is a complex polygenic disease and linked the disease to bacteria and the innate immunity.

Recently, base-pair changes in the genes for both CDI4 and toll-like receptor 4 (TLR4) have been described in humans. The LPS induced signalling through TLR4 and coreceptors CD14 as well as LPS binding protein (LBP) leads to NF- $\kappa B$ activation and cytokine expression. ${ }^{6}$ Two members of the TLRs family have been identified as an important link between innate and adaptive mucosal immune responses. ${ }^{7}$ TLR2 and TLR4 are suggested to be the main mediator of innate immune responses to LPS in vitro and in vivo. It seems that TLR4 is a principal signal transducer for LPS and TLR2 is a signal transducer for Gram positive bacterial components such as peptidoglycan lipopeptides and zymosan and certain structural variants of LPS. ${ }^{89}$ Mutations in the TLR4 receptor at residues 299 and 399 have been shown to be associated with hyporesponsiveness to inhaled endotoxin or LPS in humans. ${ }^{10}$ One of these missense polymorphisms in the fourth exon of TLR4 Asp299Gly changed the extracellular domain of the receptor. The mutation of TLR4 in mice was also shown to abolish responses to endotoxin, and to be hypersusceptible to Gram negative bacterial infection and to be insensitive to the LPS. ${ }^{11}{ }^{12}$ Cario et al ${ }^{13}$ showed that normal intestinal epithelial cells and mucosa constitutively expressed TLR3 and TLR5 and hardly expressed TLR2 and TLR4, but TLR4 was strongly upregulated in both UC and CD. The results suggested that TLR4 might have a function in protein level in IBD. The study from Japan mentioned that there is no relation between TLR4 Asp299Gly and IBD. ${ }^{14}$ They did not detect any mutation of TLR4 Asp299Gly polymorphism in IBD patients whereas two other papers have reported their positive relation in Europe. Franchimont et $a l^{15}$ have shown that TLR4 Asp299gly polymorphism was associated with CD and UC in Belgium, and Torok et $a l^{16}$ also found the Thr399Ile mutation in TLR4 gene was significantly increased in UC when compared with the controls and reported this novel association between a functional polymorphism in TLR4 and UC in Germany. These studies have prompted us to study the relation between TLR4 and UC in Chinese patients.

CD14, a GPI anchored glycoprotein expressed in monocytes/macrophages and neutrophils, not in B lymphocytes or endothelial cells, reacts efficiently with LPS complexed with LBP in serum to activate macrophages. ${ }^{17}$ CDI4 transfers LPS and other bacterial ligands (for example, peptidoglycans and lipoteichoic acid) from circulating LBP to the TLR4-MD-2 signalling complex. ${ }^{18} 19$ Binding LPS to membrane bound CD14 results in cellular activation as well as the production of proinflammatory cytokines, oxygen free radicals, nitric oxygen, and anti-inflammatory cytokines, ${ }^{20}$ and the upregulation of costimulatory molecules, which may lead to the adaptive immune response. ${ }^{21}$ LPS responsive cells, which do not contain membrane bound CDl4 (mCDI4), such as epithelial cells, become sensitive to low concentrations of LPS in the presence of soluble CDI4 (sCD14). ${ }^{22}$ Recently a polymorphism in the promoter region of the CD14 gene has been reported. This polymorphism entails a $\mathrm{T} \rightarrow \mathrm{C}$ substitution that is located at position -260 when a HaeIII restriction site is introduced..$^{23}$ The identical polymorphism has also been identified in another study, but was referred to as -159 because of a different position when starting numbering. A study shows that subjects carrying the $\mathrm{T}$ allele have significantly higher sCDI4 levels than carriers of the $\mathrm{C}$

Abbreviations: UC, ulcerative colitis; $C D$, Crohn's disease; IBD, inflammatory bowel disease; TLR4, toll-like receptor 4; LBP, LPS binding protein 
allele. ${ }^{24}$ Two papers ${ }^{25}{ }^{26}$ have reported on the association between IBD and the polymorphism CD14 C-260T, but one is associated with UC while the other is associated with CD. Moreover, Torok et $a l^{16}$ have reported that they did not find the association between the CDI4 promoter polymorphism and UC. Different results might be interpreted by genetic heterogeneity of races.

These studies investigated the possible role of TLR4/CD14 genes in LPS binding and signalling. We hypothesised that polymorphisms of the TLR4 and the CDI4 gene may be important factors for determining susceptibility to UC and may be predictive for the disease outcome. To evaluate whether these two polymorphisms contribute to the predisposition to UC, we detected TLR4 and CDI4 gene polymorphisms in Chinese patients with UC.

\section{METHODS \\ Subjects}

One hundred and fourteen patients with UC from Zhongnan Hospital of Wuhan University and other central hospitals in Wuhan city were studied. Diagnosis of UC was made by conventional clinical, radiological, endoscopic, and histological criteria. ${ }^{27}$ The patients with UC were classified according to sex (male and female) and location (left sided colitis, proctitis, and extensive colitis). Ethnically matched 160 Chinese healthy controls and 170 Dutch white healthy controls were recruited from staff and students in Wuhan University Zhongnan Hospital and Vrije Universiteit Medical Centre, Amsterdam, Netherlands (VUmc), respectively. All Chinese subjects were unrelated Han Chinese, and Dutch participants were the unrelated white subjects. All the subjects gave informed consents. The study protocol was approved by the ethics committee of Wuhan University Medical School.

\section{DNA isolation}

Genomic DNA was isolated from $5 \mathrm{ml}$ EDTA anticoagulated venous blood by conventional proteinase $\mathrm{K}$ digestion and phenol/chloroform extraction method. The positive control DNA samples of TLR4 and CD14 genes were provided by the laboratory of immunogenetics of VUmc.

\section{TLR4 Asp299Gly genotyping}

The two primer sets were designed from the TLR4 coding sequence (GenBank accession no U88880) referenced to Okayama et al ${ }^{14}$ (Fl: 5'-TTAGAAATGAAGGAAACTTGGAAA AG-3', Rl: 5'-TTTGTCAAACAATTAAATAAGTGATTAATA-3', F2: 5'-AGCATACTTAGACTACCACCTCGATG-3'， R2: 5'-GTT GCCATCCGAAATTATAAGAAAAG-3'). The PCR conditions were as follows: an initial denaturation at $94^{\circ} \mathrm{C}$ for three minutes, followed by 38 cycles of denaturing at $94^{\circ} \mathrm{C}$ for 45 seconds, annealing at $51{ }^{\circ} \mathrm{C}$ for 45 seconds, and extension at $72^{\circ} \mathrm{C}$ for 45 seconds. The final extension was continued at

Table 1 Genotypes and allele frequencies of CD14 C$260 \mathrm{~T}$ in healthy controls and patients with ulcerative colitis (UC) in the Chinese Han population

\begin{tabular}{|c|c|c|}
\hline & Healthy controls ( $n=160$ ) & UC $(n=114)$ \\
\hline Genotype & Number (\%) & Number (\%) \\
\hline $\mathrm{T} / \mathrm{T}$ & $58(36.3)$ & $42(36.8)$ \\
\hline $\mathrm{C} / \mathrm{T}$ & $77(48.1)$ & $62(54.4)$ \\
\hline $\mathrm{C} / \mathrm{C}$ & $25(15.6)$ & $10(8.8)$ \\
\hline Allele frequency & $\%$ & $\%$ \\
\hline $\mathrm{T}$ & 60.3 & 64.0 \\
\hline C & 39.7 & 36.0 \\
\hline
\end{tabular}

$72^{\circ} \mathrm{C}$ for five minutes and cooling to $4^{\circ} \mathrm{C}$. The PCR was performed using a total $25 \mu \mathrm{l}$ of the following mixture: $50 \mathrm{pmol}$ of each primer, $2.5 \mu \mathrm{l}$ of $10 \times$ buffer, $1.5 \mu \mathrm{l}$ of $25 \mathrm{mM}$ $\mathrm{MgCl}_{2}, 0.5 \mu \mathrm{l}$ of $10 \mathrm{mM}$ dNTPs, $1 \mu \mathrm{l}$ of template DNA, $1 \mu \mathrm{l}$ of AmpliTaq DNA polymerase (MBI Fermentas), and $13.5 \mu \mathrm{l}$ ddH2O. The amplification was carried out on a Perkin-Elmer thermal cycler. PCR products were analysed by electrophoresis in $2 \%$ agarose gel with ethidium bromide staining under ultraviolet transillumination.

To detect the mutation in the TLR4 fragments, the PCR based restriction fragment length polymorphism (RFLP) analysis was performed. The PCR products were digested by the restriction enzymes BsaBI and BstXI. The 139 bp PCR product was amplified by $\mathrm{Fl}$ and $\mathrm{Rl}$, and the $131 \mathrm{bp}$ fragment was amplified by F2 and R2. When digested by BsaBI, the fragments ( 139 bp for allele $G$ and $112 b p+27 b p$ for allele A respectively) were obtained. When digested by BstXI, the fragments ( $108 \mathrm{bp}+23 \mathrm{bp}$ for allele $\mathrm{G}$ and $131 \mathrm{bp}$ for allele A) were obtained. The products were separated by electrophoresis in non-denaturing polyacrylamide gels containing $8 \%$ acrylamide-bisacrylamide (29:1), 0.5× TRISborate-EDTA (TBE), $10 \%$ ammonium persulphate, and TEMED at $150 \mathrm{~V}$ for 1.5 hours. The gels were then subjected to silver staining.

\section{CD14 genotyping}

Primers of CDI4 $\mathrm{P}_{1}\left(5^{\prime}\right.$-CCTGCAGAATCCTTCCTGTT-3') and CD14 $\mathrm{P}_{2}$ (5'-TCACCTCCCCACCTCTCTT-3') were used to amplify a $107 \mathrm{bp}$ fragment of the CD14 promoter (GenBank accession no U00699). A $25 \mu \mathrm{l} \mathrm{PCR} \mathrm{amplification} \mathrm{mixture}$ containing $50 \mathrm{pmol}$ of each primer, $2.5 \mu \mathrm{l}$ of $10 \times$ buffer, $1.5 \mu \mathrm{l}$ of $25 \mathrm{mM} \mathrm{MgCl}_{2}, 0.5 \mu \mathrm{l}$ of $10 \mathrm{mM}$ dNTPs, $1 \mu \mathrm{l}$ of template DNA, $1 \mu \mathrm{l}$ of AmpliTaq DNA polymerase, and $17 \mu \mathrm{l} \mathrm{dd}_{2} \mathrm{O}$, was run in a Perkin-Elmer Thermal cycler. After an initial denaturation at $94^{\circ} \mathrm{C}$ for five minutes, 35 cycles of denaturing at $94^{\circ} \mathrm{C}$ for 30 seconds, annealing at $55^{\circ} \mathrm{C}$ for 30 seconds, and extension at $72^{\circ} \mathrm{C}$ for one minute followed. The final extension was continued at $72^{\circ} \mathrm{C}$ for seven minutes and kept in $4^{\circ} \mathrm{C}$. PCR products were analysed by electrophoresis in $2 \%$ agarose gel with ethidium bromide staining under ultraviolet transillumination. The $\mathrm{C}$ allele of the polymorphism of CD14 at position -260 contains the restriction site for Hae III, which is not present in the T allele. The PCR was restricted with Hae III and the resulting fragments ( $107 \mathrm{bp}$ for the T allele and $83 \mathrm{bp}$ and $24 \mathrm{bp}$ for the C allele, respectively) were separated on non-denaturing polyacrylamide gels containing $8 \%$ acrylamide-bisacrylamide and then silver staining.

\section{Statistics analysis}

The data were analysed using SPSS software (version 11.0, SPSS, Chicago, IL). Genotypes and allele frequencies were calculated by direct counting. Significance of the association was determined by $\chi^{2}$ test and Fisher's exact test. Departures from Hardy-Weinberg equilibrium were tested by the $\chi^{2}$ method. A value of $\mathrm{p}<0.05$ was considered significant. Odds ratios (OR) with 95\% confidence intervals (95\% CI) were calculated according to Woolf's method.

\section{RESULTS}

In our study, the functional mutation Asp299Gly of the TLR4 gene was not detected in any Chinese subject. All the PCR products were sensitive to BsaBI and resistant to BstXI, they were all wild-type homozygotes. Therefore, significant association was not seen in patients with UC and healthy controls in the Chinese subjects, which is similar to the results in Japanese. ${ }^{14}$ However, mutations TLR4 Asp299Gly occurred in $10 \%$ of the Dutch subjects.

The distributions of genotype and allele frequencies of CD14 C-260T in both the patients and the healthy controls 
Table 2 Genotype and allele frequencies of CD14 C-260T classified by sex and location of ulcerative colitis in Chinese patients

\begin{tabular}{|c|c|c|c|c|c|}
\hline & \multicolumn{3}{|c|}{ Genotype frequency (\%) } & \multicolumn{2}{|c|}{ Allele frequency (\%) } \\
\hline & $T / T$ & $C / T$ & $\mathrm{C} / \mathrm{C}$ & T & C \\
\hline \multicolumn{6}{|l|}{ Sex } \\
\hline Male $(n=64)$ & $23(35.9)$ & $37(57.8)$ & $4(6.3)$ & $83(64.8)$ & 45 (35.2) \\
\hline Female $(n=50)$ & $19(38.0)$ & $25(50.0)$ & $6(12.0)$ & $63(63.0)$ & $37(37.0)$ \\
\hline \multicolumn{6}{|l|}{ Location } \\
\hline Left sided colitis $(n=51)$ & $20(39.2)$ & $25(49.0)$ & $6(11.8)$ & 65 (63.7) & $37(36.3)$ \\
\hline $\operatorname{Proctitis}(n=19)$ & $2(10.5)$ & $10(52.6)$ & 7 (36.9) & $14(36.8)$ & $24(63.2)$ \\
\hline Extensive colitis ( $n=44$ ) & $2(4.5)$ & $27(61.4)$ & $15(34.1)$ & 31 (35.2) & $57(64.8)$ \\
\hline
\end{tabular}

were in Hardy-Weinberg equilibrium (table 1). Frequencies of $\mathrm{C} / \mathrm{C}$ genotype in healthy controls and UC were $15.6 \%$ and $8.8 \%$, respectively, and frequencies of $\mathrm{C} / \mathrm{T}$ genotype were $48.1 \%$ and $54.4 \%$, respectively. The distribution of genotypes of the CD14 C-260T was not statistically different among the healthy controls and the patients with UC in the Chinese ( $p=0.2267$ ). In table 2 , no significant differences were found in the genotype and allele frequencies of the CD14-260T among subgroups of UC, which were stratified according to sex and location of the disease. Furthermore, CD14 C-260T genotypes differed significantly in Chinese from Japanese, ${ }^{29}$ and from Dutch populations ${ }^{28}$ (table 3 ).

\section{DISCUSSION}

This study has shown that the G allele of TLR4 gene Asp299Gly was not present in the Chinese population tested. Therefore, we could not find any association between the TLR4 Asp299Gly mutated genotype and UC, similar to a study in the Japanese. ${ }^{14}$ They genotyped 108 healthy volunteers and 50 patients with UC and did not detect any mutation of the TLR4 Asp299Gly. Comparing the genotype and allele frequencies of the TLR4 Asp299Gly polymorphism among Chinese, Japanese, ${ }^{14}$ and Dutch white subjects, ${ }^{28}$ we found significant differences between Asians and Dutch white subjects. In Chinese and Japanese, the mutation of the TLR4 Asp299Gly did not occur, while in Dutch white subjects, the combination of AG and GG genotypes occurred in 10\%. Our study showed that the distribution of the TLR4 Asp299Gly polymorphism was significantly different between Asia and this western population.

CD14, the coreceptor of TLR4 for LPS, is present in two forms, mCDl4 and SCD14. ${ }^{3031}$ Membrane CD14 is expressed on the surface of monocytes and macrophages and activates through TLR4, while SCD14 facilitates the LPS binding to the cells that do not express mCD14. CD14 gene is located on the long arm of chromosome 5 (5q31-33) and consists of a single base substitution $(\mathrm{C} \rightarrow \mathrm{T})$ at position -260 in the promoter of the CDl4 gene. This polymorphism has been reported to influence the density of CDI4 expression on monocytes for the activation of monocytes to secrete inflammatory cytokines by LPS. ${ }^{23}$ The $\mathrm{T}$ variant of the -260 polymorphism can

Table 3 Genotypes of CD14 C-260T in Chinese, Japanese, and Dutch population

\begin{tabular}{llll}
\hline & $\begin{array}{l}\text { Chinese } \\
(\mathbf{n}=160)\end{array}$ & $\begin{array}{l}\text { Japanese }^{29} \\
(\mathbf{n}=527)\end{array}$ & $\begin{array}{l}\text { Dutch }^{28} \\
(\mathbf{n}=170)\end{array}$ \\
\hline T/T & $58(36.3)$ & $134(25.4)$ & $40(24)$ \\
T/C & $77(48.1)$ & $278(52.8)$ & $82(48)$ \\
C/C & $25(15.6)$ & $115(21.8)^{*}$ & $48(28) \dagger$ \\
\hline
\end{tabular}

*Chinese $v$ Japanese: $\chi^{2}(3 \times 2$ table): $7.965, p=0.0186$; $\uparrow$ Chinese $v$ Dutch: $\chi^{2}(3 \times 2$ table): $10.416, p=0.0055$. promote the transcription of CD14 gene and cause higher expression of CD14 on monocytes, which may lead to an increased inflammatory response. Furthermore, subjects carrying the $\mathrm{T}$ allele have significantly higher soluble CD14 levels than carriers of the $\mathrm{C}$ allele. Therefore, the CD14 polymorphism may be a genetic factor responsible for individual differences in the expression of CDI4 and inflammatory response to luminal bacterial infections.

Zareie et $a l^{32}$ found that intestinal lamina propria mononuclear cells (LPMCs) of patients with CD were spontaneously activated by LPS. Active intestinal inflammation in IBD patients has shown increased expression of CDI4 in LPMCs. $^{33}{ }^{34}$ Therefore, activation of the CD14 pathway in LPMCs or intestinal epithelium may be a trigger in the inflammatory response leading to increased production of proinflammatory cytokines and mucosal damage. Two clinical studies have shown an association between polymorphism in the promoter of the CDI4 gene and myocardial infarction. ${ }^{23}{ }^{35}$ One Japanese research group confirmed that the C-260T polymorphism in the promoter of the CDI4 monocyte receptor gene was associated with acute myocardial infarction rather than with coronary atherosclerosis. ${ }^{36}$ Eng et $a l^{37}$ found an association between Chlamydia pneumoniae infection and CDI4 polymorphism in the Chinese population in Taiwan. Linkage between CD14 polymorphism and IBD has also been studied. In a German population, an association of $\mathrm{CD}$ with allele $\mathrm{T}$ and the T/T genotype of CDI4 gene has been found significant, which may be interpreted by a changed immune response to LPS contributing to the genetic predisposition to CD but not to UC. ${ }^{25}$ However, it has been shown that the CD14 gene in 5q31-33 region had a significant linkage with UC in the Japanese population ${ }^{26}$ and in the Canadian population. ${ }^{28}$

Our study has shown that CD14 C-260T polymorphism was not associated with UC in the Chinese population. The frequency of the $\mathrm{C} / \mathrm{C}$ genotype in healthy controls (15.6\%) was higher than in UC $(8.8 \%)$, the $\mathrm{C} / \mathrm{T}$ genotype in UC (54.4\%) was higher than in healthy controls $(48.1 \%)$, but neither of them is statistically significant. We did not find differences of CD14 C-260T between subgroups of UC as shown in table 2. Furthermore, the distributions of CD14 C260T genotypes were significantly different Chinese and Japanese, ${ }^{29}$ and between Chinese and Dutch white subjects ${ }^{28}$ (table 3), which demonstrated ethnic genetic differences. The study implicates that the polymorphism of CD14 C-260T does not confer a genetic predisposition to UC. The lack of association of CDl4 gene with UC in the Chinese population may be explained by genetic heterogeneity, and possibly a type 2 statistical error.

In summary, both the polymorphism of CD14 C-260T and TLR4 Asp299Gly were not associated with UC in the Chinese population, but the distributions of these two gene polymorphisms have ethnic differences. 


\section{ACKNOWLEDGEMENTS}

We thank Professor H S Luo and Dr Y J Ding of the People's Hospital of Wuhan University, Professor X H Hou and K F Zhou of Union Hospital and Professor N Z Liu and Associate Professor Q Zhao of Tongji Hospital of Huazhong Science and Technology University for assistance with collecting DNA samples for IBD patients. We also thank Ms Jolein Pleijster for assistance with typing most of the Dutch control cohort both CDI4 and TLR4 genes.

\section{Authors' affiliations}

Q S Guo, B Xia, Y Jiang, L Cheng, J Li, Department of Internal Medicine and Geriatrics, Research Centre of Digestive Diseases of Zhongnan Hospital; Laboratory of Inflammation and Autoimmune Diseases of the Institute of Allergy and Immune Related Diseases, Wuhan University Medical School, Wuhan, PR of China

S A Morré, J B A Crusius, A S Peña, Laboratory of Immunogenetics, VU University Medical Centre, Amsterdam, Netherlands

Funding: the study was supported by grants from the State Natural Science Foundation of China (30370638) and Hubei provincial public health bureau (JX1A14).

Conflicts of interest: none.

Ethics approval: all the subjects gave informed consent and the study protocol was approved by the ethics committee of Wuhan University Medical School.

\section{REFERENCES}

1 Xia B, Crusius J, Meuwissen S, et al. Inflammatory bowel disease: definition, epidemiology, etiologic aspects, and immunogenetic studies. World J Gastroenterol 1998;4:446-58.

2 Hugot JP, Chamaillard M, Zouali $H$, et al. Association of NOD2 leucine-rich repeat variants with susceptibility to Crohn's disease. Nature $2001 ; 411: 599-603$

3 Inohara N, Ogura Y, Fontalba A, et al. Host recognition of bacterial muramyl dipeptide mediated through NOD2. Implications for Crohn's disease. J Biol Chem 2003;278:5509-12.

4 Ogura $\mathrm{Y}$, Bonen DK, Inohara N, et al. A frameshift mutation in NOD2 associated with susceptibility to Crohn's disease. Nature 2001;411:603-6.

5 Girardin SE, Boneca IG, Viala J, et al. Nod2 is a general sensor of peptidoglycan through muramyl dipeptide (MDP) detection. J Biol Chem 2003;278:8869-72.

6 Chow JC, Young DW, Golenbock DT, et al. Toll-like receptor-4 mediates lipopolysaccharide-induced signal transduction. J Biol Chem 1999;274: 10689-92.

7 Cario E, Rosenberg IM, Brandwein SL, et al. Lipopolysaccharide activates distinct signaling pathways in intestinal epithelial cell lines expressing toll-like receptors. J Immunol 2000; 164:966-72.

8 Beutler B. Th4: central component of the sole mammalian LPS sensor. Curr Opin Immunol 2000;12:20-6.

9 Schwandner R, Dziarski R, Wesche H, et al. Peptidoglycan- and lipoteichoic acid-induced cell activation is mediated by toll-like receptor 2. J Biol Chem 1999;274:17406-9.

10 Arbour NC, Lorenz E, Schutte BC, et al. TLR4 mutations are associated with endotoxin hyporesponsiveness in humans. Nat Genet 2000;25:187-91.

11 Hoshino K, Takeuchi O, Kawai T, et al. Cutting edge: Toll-like receptor 4 (TLR4)-deficient mice are hyporesponsive to lipopolysaccharide: evidence for TLR4 as the Lps gene product. J Immunol 1999;162:3749-52.

12 Yoshida S, Goto Y, Miyamoto H, et al. Association of Lps gene with natural resistance of mouse macrophages against Legionella pneumophila. FEMS Microbiol Immunol 1991;4:51-6.

13 Cario E, Podolsky DK. Differential alteration in intestinal epithelial cell expression of toll-like receptor 3 (TLR3) and TLR4 in inflammatory bowel disease. Infect Immun 2000;68:7010-17.
14 Okayama N, Fujimura K, Suehiro Y, et al. Simple genotype analysis of the Asp299Gly polymorphism of the toll-like receptor-4 gene that is associated with lipopolysaccharide hyporesponsiveness. J Clin Lab Anal 2002;16:56-8.

15 Franchimont D, Vermeire S, El Housni H, et al. Deficient host-bacteria interactions in inflammatory bowel disease? The toll-like receptor (TLR)-4 Asp299gly polymorphism is associated with Crohn's disease and ulcerative colitis. Gut 2004;53:987-92.

16 Torok HP, Glas J, Tonenchi L, et al. Polymorphisms of the lipopolysaccharidesignaling complex in inflammatory bowel disease: association of a mutation in the toll-like receptor 4 gene with ulcerative colitis. Clin Immunol 2004; 112:85-91.

17 Wright SD, Ramos RA, Tobias PS, et al. CD14, a receptor for complexes of lipopolysaccharide (LPS) and LPS binding protein. Science 1990:249:1431-3.

18 da Silva CJ, Soldau K, Christen U, et al. Lipopolysaccharide is in close proximity to each of the proteins in its membrane receptor complex. transfer from CD1 4 to TLR4 and MD-2. J Biol Chem 2001;276:21129-35.

19 Pugin J, Heumann ID, Tomasz A, et al. CD14 is a pattern recognition receptor. Immunity 1994;1:509-16.

20 Schutt C. CD14. Int J Biochem Cell Biol 1999;31:545-9.

21 Medzhitov R, Janeway C Jr. Innate immunity. N Engl J Med 2000;343:338-44.

22 Frey EA, Miller DS, Jahr TG, et al. Soluble CDI4 participates in the response of cells to lipopolysaccharide. J Exp Med 1992;176:1665-71.

23 Hubacek JA, Rothe G, Pit'ha J, et al. C(-260)-->T polymorphism in the promoter of the CD14 monocyte receptor gene as a risk factor for myocardial infarction. Circulation 1999;99:3218-20.

24 Baldini M, Lohman IC, Halonen $M$, et al. A Polymorphism* in the $5^{\prime}$ flanking region of the CD14 gene is associated with circulating soluble CD14 levels and with total serum immunoglobulin E. Am J Respir Cell Mol Biol 1999;20:976-83

25 Klein W, Tromm A, Griga T, et al. A polymorphism in the CD14 gene is associated with Crohn disease. Scand J Gastroenterol 2002;37:189-91.

26 Obana N, Takahashi S, Kinouchi Y, et al. Ulcerative colitis is associated with a promoter polymorphism of lipopolysaccharide receptor gene, CDI4. Scand J Gastroenterol 2002;37:699-704.

27 Lennard-Jones JE. Classification of inflammatory bowel disease. Scand J Gastroenterol Suppl 1989;170:2-6.

28 Ouburg S, Mallant-Hent R, Crusius JBA, et al. The roll-like receptor 4 (TLR4) Asp299Gly polymorphism is associated with colonic localisation of Crohn's disease without a major role for the Saccharomyces cerevisiae mannan-LBPCD14-TLR4 pathway. Gut 2005;54:439-40.

29 Hohda S, Kimura A, Sasaoka T, et al. Association study of CD14 polymorphism with myocardial infarction in a Japanese population. Jpn Heart J 2003;44:613-22.

30 Schutt C, Schilling T, Grunwald U, et al. Endotoxin-neutralizing capacity of soluble CD14. Res Immunol 1992;143:71-8.

31 Simmons DL, Tan S, Tenen DG, et al. Monocyte antigen CD14 is a phospholipid anchored membrane protein. Blood 1989;73:284-9.

32 Zareie M, Singh PK, Irvine EJ, et al. Monocyte/macrophage activation by normal bacteria and bacterial products: implications for altered epithelial function in Crohn's disease. Am J Pathol 2001;158:1101-9.

33 Grimm MC, Pavli P, Van de PE, et al. Evidence for a CDI4+ population of monocytes in inflammatory bowel disease mucosa--implications for pathogenesis. Clin Exp Immunol 1995;100:291-7

34 Rugtveit J, Haraldsen G, Hogasen AK, et al. Respiratory burst of intestinal macrophages in inflammatory bowel disease is mainly caused by $\mathrm{CD} 14+\mathrm{L} 1+$ monocyte derived cells. Gut 1995;37:367-73.

35 Unkelbach K, Gardemann A, Kostrzewa M, et al. A new promoter polymorphism in the gene of lipopolysaccharide receptor CD14 is associated with expired myocardial infarction in patients with low atherosclerotic risk profile. Arterioscler Thromb Vasc Biol 1999;19:932-8.

36 Shimada K, Watanabe Y, Mokuno H, et al. Common polymorphism in the promoter of the CD14 monocyte receptor gene is associated with acute myocardial infarction in Japanese men. Am J Cardiol 2000;86:682-4

37 Eng HL, Chen $\mathrm{CH}$, Kuo CC, et al. Association of $\mathrm{CD} 14$ promoter gene polymorphism and Chlamydia pneumoniae infection. J Infect Dis 2003;188:90-7.

38 Rioux JD, Silverberg MS, Daly MJ, et al. Genomewide search in Canadian families with inflammatory bowel disease reveals two novel susceptibility loci. Am J Hum Genet 2000;66:1863-70. 